\title{
KUALITAS SENSORIS YOGHURT SINBIOTIK MENGGUNAKAN PATI TERMODIFIKASI DARI UMBI UWI UNGU (Dioscorea alata)
}

\author{
Yaumi, R. Hadju*, A. Yelnetty, N.N. Lontaan
}

Fakultas Peternakan Universitas Sam Ratulangi Manado 95115.

\begin{abstract}
ABSTRAK
Penelitian ini dilakukan untuk mengetahui dan mengkaji kualitas sensorik yoghurt sinbiotik menggunakan pati termodifikasi dari umbi uwi ungu (Dioscorea alata). Materi yang digunakan dalam penelitian ini adalah $4,800 \mathrm{~mL}$ susu UHT, skim milk $8 \%$, sukrosa $6 \%$, pati termodifikasi dari umbi uwi ungu (Dioscorea alata) dengan konsentrasi 0\%, $0,1 \%, 0,2 \%, 0,3 \%, 0,4 \%, 0,5 \%$, aquadest, alkohol, spritus, bakteri Steptococcus thermopilus, bakteri Lactobacillus bulgaricus, bakteri Lactobacillus rhamnosus, dan bahan - bahan untuk pengujian sensoris yang digunakan adalah air mineral, dan ketimun. Penelitian ini menggunakan Rancangan Acak Lengkap (RAL) dengan 6 perlakuan dan panelis adalah sebagi ulangan. Pengukuran data organoleptik dengan menggunakan uji hedonik menggunakan 44 panelis tidak terlatih. Untuk variabel yang berbeda sangat nyata dilanjutkan dengan uji BNJ. Variabel yang diukur adalah warna, aroma, tekstur, kekentalan dan cita rasa. Hasil analisis ragam menunjukan bahwa pemberian pati termodifikasi dari umbi uwi ungu (Dioscorea alata) berbeda sangat nyata terhadap warna, aroma, tekstur, kekentalan dan cita rasa. Perlakuan dengan pemberian pati termodifikasi dari umbi uwi ungu (Dioscorea alata) sebanyak 0,4\% memberikan nilai yang baik terhadap kualitas sensoris khususnya pada cita rasa dan tekstur yoghurt sinbiotik.
\end{abstract}

*Korespondensi(corresponding Author)

Email: rhadju19@gmail.com
Kata Kunci : Yoghurt, pati termodifikasi, umbi uwi ungu, sifat sensoris

\begin{abstract}
YOGHURT SINBIOTIK SENSORY QUALITY USING MODIFIED STARCH FROM BULBS UBE PURPLE (Dioscorea Alata). The materials used in this study were $4.800 \mathrm{ml}$ UHT milk, skim milk 8\%, 6\% sucrose, starch modified from Uwi purple tuber (Dioscorea alata) with a concentration of $0 \%, 0.1 \%, 0.2 \%, 0.3 \%, 0.4 \%, 0.5 \%$, distilled water, alcohol, spritus, Thermopilus Streptococcus bacteria, Lactobacillus bulgaricus, Lactobacillus rhamnosus, and materials that were used for sensory testing is mineral water, and cucumber. This study uses a completely randomized design (CRD) with 6 treatments and the panelists were as replications. Organoleptic data measurement using hedonic test using 44 trained panelists. For a highly significant variable followed by HSD test. The variables were the color, aroma, texture, consistency and taste. Results of analysis of variance showed that the administration of the modified starch from Uwi purple tuber (Dioscorea alata) highly significant for color, aroma, texture, consistency and taste. Treatment with modified starch provision of uwi purple tuber (Dioscorea alata) as much as $0,4 \%$ of the best value of sensory qualities in the taste and texture of synbiotic yoghurt.
\end{abstract}

Keywords: yoghurt, modified starch, tuber uwi purple, sensory properties 


\section{PENDAHULUAN}

Produk susu fermentasi sebagai pangan fungsional yang bermanfaat bagi kesehatan tubuh manusia dewasa ini berkembang pesat baik dari segi kualitas maupun kuantitasnya. Hal ini disebabkan karena semakin meningkatnya kesadaran dan pemahaman masyarakat akan makanan dan minuman yang menyehatkan. Salah satu produk susu fermentasi yang dikenal oleh masyarakat Indonesia adalah yoghurt.

Yoghurt merupakan produk fermentasi susu yang mempunyai cita rasa spesifik sebagai hasil fermentasi oleh bakteri asam laktat dari spesies Streptococcus thermophilus dan Lactobacillus bulgaricus. Yoghurt yang baik untuk kesehatan disebut juga dengan yoghurt sinbiotik, yaitu yoghurt yang mengandung bakteri probiotik dan bahan prebiotik. Sinbiotik merupakan istilah yang digunakan dalam penamaan pada produk makanan yang didalamnya terdapat campuran antara probiotik dan prebiotik. Bakteri hidup yang bermaanfaat bagi kesehatan disebut dengan bakteri probiotik. Bakteri probiotik adalah bakteri asam laktat yang dapat hidup dalam salauran pencernaan yang memberi manfaat bagi inang atau host dimana bakteri berada. Prebiotik adalah ingredient yang tidak dapat dicerna oleh tubuh tapi dapat dimanfaatkan oleh bakteri probiotik sebagai sumber energi. Salah satu prebiotik yang dapat digunakan adalah dalam bentuk pati termodifikasi secara thermal dari umbi uwi ungu (Dioscorea alata) (Abubakar et al., 1998). Umbi uwi ungu (Dioscorea alata) merupakan tanaman berumbi yang tergolong kedalam familia Dioscoreaceae dari genus Dioscorea yang mengandung inulin sebesar $7,54 \%$ yang dapat disesuaikan sebagai prebiotik (Winarti et al., 2011).

Pati termodifikasi adalah pati yang diberi perlakuan tertentu dengan tujuan untuk menghasilkan sifat pati yang lebih baik untuk memberbaiki sifat sebelumnya atau merubah beberapa sifat lainnya. Modifikasi pati dapat dilakukan dengan cara pemanasan, asam, alkali, zat pengoksidasi atau bahan kimia lainnya yang akan menghasilkan gugus kimia baru atau perubahan bentuk, ukuran serta struktur molekul pada pati. Pati termodifikasi dari umbi uwi ungu (Dioscorea alata) juga dapat digunakan sebagai sumber prebiotik, selain itu pati juga dapat berfungsi sebagai pengemulsi, stabilizer, emulsifier untuk meningkatkan kualitas yoghurt yang dihasilkan.

Dalam pembuatan yoghurt sinbiotik yang perlu diperhatikan adalah lama proses fermentasinya, guna memberi cita rasa atau flavor, aroma, warna dan tekstur dari yoghurt yang dihasilkan. Penggunaan 
tepung prebiotik dari umbi uwi ungu (Dioscorea alata) sebanyak $1 \%$ menghasilkan yoghurt sinbiotik yang terbaik (Yelnetty et al., 2019).

Berdasarkan hal tersebut diatas, maka telah dilakukan penelitian pembuatan yoghurt sinbiotik menggunakan pati termodifikasi dari umbi uwi ungu (Dioscora alata) dan Lactobacillus rhamnosus sebagai sumber probiotik guna mengetahui kualitas sensoris yoghurt sinbiotik yang dihasilkan dengan pengujian cita rasa, warna, aroma, tekstur dan kekentalan yang dihasilkan.

\section{MATERI DAN METODE PENELITIAN}

\section{Waktu dan Tempat Penelitian}

Penelitian ini telah dilaksanakan pada Tanggal 14 Desember 2018 sampai Tanggal 01 Maret 2019 di Laboratorium Teknologi Hasil Ternak Fakultas Peternakan, Universitas Sam Ratulangi Manado.

\section{Materi Penelitian}

\section{Bahan}

Bahan yang digunakan dalam penelitian ini adalah 4,800 $\mathrm{mL}$ susu UHT, skim milk 8\%, sukrosa $6 \%$, pati termodifikasi dari umbi uwi ungu (Dioscorea alata) dengan konsentrasi 0\%,
$0,1 \%, 0,2 \%, 0,3 \%, 0,4 \%, 0,5 \%$, aquadest, alkohol, spritus, Bakteri Steptococcus thermopilus, Bakteri Lactobacillus bulgaricus, Bakteri Lactobacillus rhamnosus, dan bahan - bahan untuk pengujian sensoris yang digunakan adalah air mineral, dan ketimun.

Alat

Peralatan yang digunakan dalam penelitian ini adalah erlenmeyer, tabung reaksi, gelas ukur, gelas piala, autoclave, oven listrik, inkubator, waterbath, spatula, panci, pisau, pengaduk, kompor, wadah (cup), lemari pendingin, saringan, parutan, pensil, penghapus, kertas, dan tusuk gigi.

\section{Metode Penelitian}

Penelitian ini menggunakan Rancangan Acak Lengkap (RAL) dengan 6 perlakuan dan panelis adalah sebagi ulangan. Pengukuran data organoleptik dengan menggunakan uji hedonik menggunakan 44 panelis tidak terlatih (Steel and Torrie, 1991). Konsentrasi pati termodifikasi dari umbi uwi ungu (Dioscorea alata) yang ditambahkan (P) adalah sebagai berikut :

P0 : Tanpa pati termodifikasi

P1 : Pemberian pati termodifikasi $0,1 \%+$ Starter yoghurt (St,Lb,Lr)

P2 : Pemberian pati termodifikasi 0,2\% + starter yoghurt (St,Lb,Lr) 
P3 : Pemberian pati termodifikasi $0,3 \%+$ starter yoghurt (St,Lb,Lr)

P4 : Pemberian pati termodifikasi 0,4\% + starter yoghurt (St,Lb,Lr)

P5 : Pemberian pati termodifikasi $0,5 \%+$ starter yoghurt (St,Lb,Lr)

\section{Prosedur Penelitian}

\section{Pembuatan Pati}

Pertama-tama umbi uwi ungu (Dioscorea alata) dikupas, dicuci bersih, direndam dalam air selama 1 hari, kemudian diparut, lalu diperas dengan kain peras dan diamkan selama 20 menit, diambil fitratnya (endapanya), kemudian dipanaskan selama 15 menit pada suhu $70^{\circ} \mathrm{C}$, setelah itu dikeringkan dioven pada suhu $56^{\circ} \mathrm{C}$ selama 24 jam, lalu diblender dan jadilah pati.

\section{Pembuatan Pati Termodifikasi}

Proses modifikasi pati alami dari umbi uwi ungu (Dioscorea alata) disuspensikan dengan cara menambahkan air dengan perbandingan pati dan air yaitu 1 : 3. Kemudian suspensi tersebut dipanaskan dalam autoclave pada suhu $110^{\circ} \mathrm{C}$ dan $121^{\circ} \mathrm{C}$ selama 30 menit. Setelah dipanaskan suspensi pati didinginkan pada suhu ruang selama 20 menit dan dilanjutkan dengan penyimpanan pada suhu $4^{\circ} \mathrm{C}$ selama 24 jam. Lalu dikeringkan pada suhu $60^{\circ} \mathrm{C}$ selama 24 jam dan setelah itu dihaluskan menggunakan blender, pati yang telah dihaluskan diayak 100 mesh. Setelah itu pati termodifikasi dikemas dengan menggunakan plastik dan ditutup rapat (Sajilata, et al, 2006).

\section{Pembuatan Starter Yoghurt Sinbiotik}

Proses pembuataan starter bakteri asam laktat yang digunakan yakni skim milk $8 \%$, ditambahkan sukrosa $1 \%$, aquades $250 \mathrm{ml}$ dimasukkan dalam elemeyer, dihomegenisasi selama 3 menit, kemudian disterilkan pada suhu $115^{\circ} \mathrm{C}$ selama 15 menit, lalu dinginkan sampai temperatur $45^{\circ} \mathrm{C}$ pada suhu ruang. Selanjutnya inokulasi masing-masing dengan bakteri asam laktat yang digunakan 3\% (Streptococcus Thermophillus, Lactobacillus burgaricus dan Lactobacillus rhamnosus). Inkubasi dilakukan pada suhu $36^{\circ} \mathrm{C}$ selama 16 jam (Yelnetty et al, 2019).

\section{Pembuatan Yoghurt Sinbiotik}

Proses pembuatan yoghurt sinbiotik menggunakan bahan $800 \mathrm{~mL}$ susu UHT, tambahkan skim milk $8 \%$,sukrosa $6 \%$, dan pati termodifikasi sebanyak $(0 \%, 0,1 \%$, $0,2 \%, 0,3 \%, 0,4 \%, 0,5 \%)$ dihomogenisasi 3 menit, kemudian dipasteurisasi pada suhu $80^{\circ} \mathrm{C}$ selama 15 menit, lakukan pendinginan sampai temperatur $40^{\circ} \mathrm{C}$ pada suhu ruang, selanjutnya diinokulasi dengan starter yang telah disiapkan terlebih dahulu sebanyak 3\% dengan perbandingan antara bakteri S. thermopillus dan L. Bulgaricus, dan L. rhamnosus. Inkubasi dalam 
inkubator pada suhu $43^{\circ} \mathrm{C}$ selama 6 jam kemudian yoghurt dikemas dalam wadah tertutup, lalu disimpan pada lemari es pada suhu $4^{\circ} \mathrm{C}$.

\section{Variabel Penelitian}

Penelitian ini menggunakan uji organoleptik yang menggunakan indra manusia sebagai tolak ukur penilaian dan menggunakan skala hedonik (warna, aroma, tekstur, kekentalan dan cita rasa). Dimana panelis yang digunakan adalah 44 orang panelis yang tidak terlatih.

Variabel yang akan diamati adalah :

\section{Warna}

Kriteria penilaian warna yoghurt sinbiotik pati termodifikasi umbi uwi ungu (Dioscorea alata) adalah sebagai berikut: 7 = Sangat menarik, $6=$ Menarik, $5=$ Agak menarik, $4=$ Netral, $3=$ Agak tidak menarik, 2 = Tidak menarik, 1 = Sangat tidak menarik.

\section{Aroma}

Kriteria penilaan untuk aroma yoghurt sinbiotik pati termodifikasai umbi uwi ungu (Dioscorea alata) adalah sebagai berikut : $7=$ Sangat suka, $6=$ Suka, $5=$ Agak suka, 4 = Netral, 3 = Agak tidak suka, $2=$ Tidak suka, $1=$ Sangat tidak suka .

\section{Tekstur}

Kriteria penilaian untuk tekstur pada yoghurt sinbiotik pati termodifikasi umbi uwi ungu (Dioscorea alata) adalah sebagai berikut : $7=$ Sangat lembut, $6=$ Lembut, 5 = Agak lembut, $4=$ Netral, $3=$ Agak tidak lembut, $2=$ Tidak lembut, $1=$ Sangat tidak lembut.

\section{Kekentalan}

Kriteria penilaian untuk cita rasa adalah sebagai berikur : 7 = Sangat enak, 6 = Enak, 5 = Agak enak, $4=$ Netral, $3=$ Agak tidak enak, 2 = Tidak enak, $1=$ Sangat tidak enak.

\section{Cita Rasa}

Kriteria penilaian untuk cita rasa adalah sebagai berikur :7 = Sangat enak, 6 = Enak, 5 = Agak enak, $4=$ Netral, $3=$ Agak tidak enak, 2 = Tidak enak, $1=$ Sangat tidak enak

\section{HASIL DAN PEMBAHASAN}

Hasil penelitian pengaruh perlakuan terhadap kualitas sensoris yoghurt sinbiotik menggunakan pati termodifikasi dari umbi uwi ungu (Dioscorea alata) dapat dilihat pada Tabel 1 
Tabel 1. Rataan Pengaruh Perlakuan Terhadap Sifat Sensoris Yoghurt Sinbiotik Umbi Uwi Ungu (Dioscorea alata)

\begin{tabular}{lcccccc}
\hline \multicolumn{7}{c}{ Perlakuan Pati Termodifikasi } \\
\hline Variabel & $\mathrm{P} 0$ & $\mathrm{P} 1$ & $\mathrm{P} 2$ & $\mathrm{P} 3$ & $\mathrm{P} 4$ & $\mathrm{P}$ \\
& $0 \%$ & $0,1 \%$ & $0,2 \%$ & $0,3 \%$ & $0,4 \%$ & $0,5 \%$ \\
\hline Warna & $4,86^{\mathrm{c}}$ & $4,91^{\mathrm{c}}$ & $6,02^{\mathrm{a}}$ & $5,75^{\mathrm{ab}}$ & $5,16^{\mathrm{bc}}$ & $4,86^{\mathrm{c}}$ \\
Aroma & $4,14^{\mathrm{b}}$ & $4,16^{\mathrm{b}}$ & $3,98^{\mathrm{b}}$ & $4,20^{\mathrm{b}}$ & $5,86^{\mathrm{a}}$ & $6,07^{\mathrm{a}}$ \\
Tekstur & $5,86^{\mathrm{a}}$ & $4,96^{\mathrm{b}}$ & $5,07^{\mathrm{b}}$ & $5,09^{\mathrm{b}}$ & $6,16^{\mathrm{a}}$ & $5,80^{\mathrm{a}}$ \\
Kekentalan & $4,00^{\mathrm{b}}$ & $5,91^{\mathrm{a}}$ & $6,07^{\mathrm{a}}$ & $4,59^{\mathrm{b}}$ & $5,48^{\mathrm{a}}$ & $4,32^{\mathrm{b}}$ \\
Cita rasa & $5,00^{\mathrm{b}}$ & $4,77^{\mathrm{b}}$ & $4,93^{\mathrm{b}}$ & $5,14^{\mathrm{b}}$ & $6,02^{\mathrm{a}}$ & $5,89^{\mathrm{a}}$ \\
\hline
\end{tabular}

Keterangan : Superskrip yang berbeda pada baris yang sama menunjukkan perbedaan nyata $(\mathrm{P}<0,01)$.

\section{Warna Yoghurt Sinbiotik Umbi Uwi Ungu (Dioscorea alata)}

Rataan nilai warna pada yoghurt sinbiotik terhadap sifat sensoris yoghurt sinbiotik menggunakan pati termodifikasi dari umbi uwi (Dioscorea alata)

berkisar antara 4,05 - 6,07 dari perlakuan P0 - perlakuan P5.

Hasil analisis sidik ragam menunjukkan bahwa perlakuan penambahan pati termodifikasi dari umbi uwi ungu (Dioscorea alata) P0 0\%, P1 0,1\%, P2 0,2\%, P3 0,3\%, P4 0,4\% dan P5 $0,5 \%$ memberikan pengaruh berbeda sangat nyata $(\mathrm{P}<0.01)$ terhadap warna yoghurt sinbiotik yang dihasilkan. Berdasarkan hasil uji lanjut menunjukkan bahwa warna pada yoghurt sinbiotik dengan penambahan pati termodifikasi dari umbi uwi ungu (Dioscorea alata) pada perlakuan P2 dengan nilai 6,02 berbeda sagat nyata $(\mathrm{P}<0.01)$ dengan perlakuan $\mathrm{P} 4$ dengan nilai 5,16 P1 dengan nilai 4,91 P5 dengan nilai 4.86 dan P0 dengan nilai 4.86, tetapi tidak berbeda sangat nyata dengan perlakuan P3 dengan nilai 5,75. Selanjutnya penambahan pati termodifikasi dari umbi uwi unggu (Dioscorea alata) dengan perlakuan P4 dengan nilai 5,16 berbeda sangat nyata $(\mathrm{P}<0.01)$ dengan perlakuan P2 dengan nilai 6,02 P3 dengan nilai 5,75 P1 dengan nilai 4,91 P5 dengan nilai 4,86 dan P0 dengan nilai 4,86. Hal yang sama juga terjadi pada perlakuan P1 dengan nilai 4,91 berbeda sangat nyata $(\mathrm{P}<0.01)$ dengan perlakuan $\mathrm{P} 2$ dengan nilai 6,02 P3 dengan nilai 5,75 dan P4 dengan nilai 5,16 tetapi tidak berbeda sangat nyata dengan perlakuan P5 dengan nilai 4,86 dan P0 dengan nilai 4,86. Hal ini menunjukkan bahwa perlakuan warna pada yoghurt memberikan pengaruh yang berbeda sangat nyat karena panelis lebih menyukai warna yoghurt sinbiotik dengan perlakuan pada penambahan pati termodifikasi dari umbi uwi ungu ( Dioscorea alata) di P2 dengan 
nilai 6,02 yang termasuk dalam kategori menarik.

Warna pada yoghurt yang dihasilkan hampir semua sama yaitu putih kecoklatan. Salah satu permasalahan utama pada tepung uwi adalah perubahan dan pencoklatan produk. Hal ini terkait dengan reaksi browning enzimatis akibat adanya senyawa fenolik larut air khususnya ohydroxy or trihydroxy phenolics oleh phenol oxidase pada uwi (Onimawo dan Akubor, 2012; Martin dan Rubeste, 1976). Amilopektin pada pati umbi uwi adalah $82 \%$. Amilopektin menimbulkan gel yang transparan, sehingga memberikan efek terang pada pati (Suryono, Harijono dan Yunianta, 2013).

\section{Aroma Yoghurt Sibiotik Umbi Uwi Ungu (Dioscorea alata)}

Rataan nilai aroma pada yoghurt terhadap sifat sensoris yoghurt sinbiotik menggunakan pati termodifikasi dari umbi uwi ungu (Dioscorea alata) berkisar antara 4,05 - 6,07 dari perlakuan P0 - perlakuan P5.

Hasil analisis sidik ragam menunjukkan bahwa perlakuan penambahan pati termodifikasi dari umbi uwi ungu (Dioscorea alata) P0 0\%, P1 $0,1 \%, \mathrm{P} 2$ 0,2\%, P3 0,3\%, P4 0,4\% dan P5 $0,5 \%$ memberikan pengaruh yang berbeda sangat nyata $(\mathrm{P}<0.01)$ terhadap aroma yoghurt sinbiotik yang dihasilkan. Berdasarkan hasil uji lanjut BNJ menunjukkan bahwa aroma pada yoghurt sinbiotik dengan penambahan pati termodifikasi dari umbi uwi ungu (Dioscorea alata) pada perlakuan P5 dengan nilai 6,07 berbeda sangat nyata $(\mathrm{P}<0.01)$ dengan perlakuan $\mathrm{P} 3$ dengan nilai 4,20 P1 dengan nilai 4,16 P0 dengan nilai 4,14 dan P2 dengan nilai 4,05 tetapi tidak berbeda sangat nyata dengan perlakuan P4 dengan nilai 5,86. Hal ini menunjukkan bahwa perlakuan aroma pada yoghurt memberikan pengaruh yang berbeda sangat nyata karena panelis lebih menyukai aroma yoghurt sinbiotik dengan perlakuan pada penambahan pati termodifikasi dari umbi uwi ungu ( Dioscorea alata) karena nilai pada perlakuan P5 dengan nilai 6,07 menunjukkan kategori suka terhadap yoghurt sinbiotik.

Perbedaan aroma pada yoghurt dengan penambahan pati termodifikasi dari umbi uwi ungu (Dioscorea alata) berubah karena terjadinya pencampuran antara umbi uwi dengan bahan-bahan lain. Yoghurt memiliki karakteristik aroma yang khas seperti aroma asam. Aroma ini timbul karena selama proses fermentasi terjadi perubahan laktosa susu menjadi asam laktat oleh bakteri asam laktat. Asam laktat inilah yang menyebabkan yoghurt memiliki aroma khas asam. Aroma produk yoghurt 
disebabkan oleh senyawa-senyawa volatil yang terbentuk sehingga menimbulkan aroma asam. Selain berperan dalam pembentukan gel, asam laktat juga memberikan ketajaman rasa dan menentukan aroma asam dari yoghurt (Anindita, 2002).

Parameter aroma sangat berkaitan dengan parameter rasa. Aroma pada yoghurt dipengaruhi oleh asam laktat, sisasisa asetaldehid, diasetil, asam asetat, dan bahan-bahan mudah menguap lainnya setelah proses fermentasi. Pada awal fermentasi, Streptococcus thermophilus tumbuh dengan cepat dan mengakibatkan akumulasi asam laktat dan asam asetat, asetal dehida, diasetil serta asam format. Adanya zat-zat tersebut dan perubahan potensial oksidasi-reduksi pada medium (yoghurt), merangsang pertumbuhan Lactobacillus bulgaricus (Oberman, 1985).

\section{Tekstur Yoghurt Sinbiotik Umbi Uwi Ungu (Dioscorea alata)}

Rataan nilai tekstur pada yoghurt terhadap sifat sensoris yoghurt sinbiotik menggunakan pati termodifikasi dari umbi uwi ungu (Dioscorea alata) berkisar antara 4,98 - 6,16 dari perlakuan P0 - perlakuan P5.

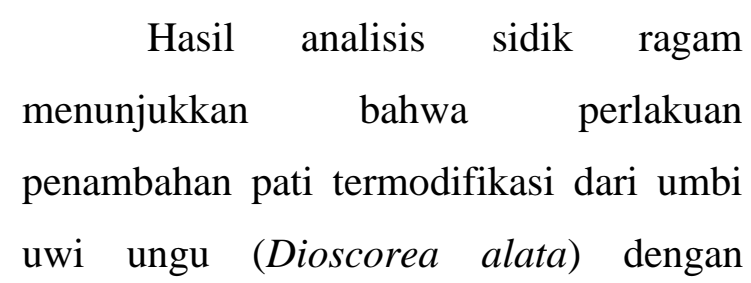

perlakuan P0 0\%, P1 0,1\%, P2 0,2\%, P3 0,3\%, P4 0,4\% dan P5 0,5\% memberikan pengaruh yang berbeda sangat nyata $(\mathrm{P}<0.01)$ terhadap tekstur yoghurt sinbiotik yang dihasilkan. Berdasarkan hasil uji lanjut BNJ menunjukkan bahwa tekstur pada yoghurt dengan penambahan pati termodifikasi dari umbi uwi ungu (Dioscorea alata) pada perlakuan P4 dengan nilai 6,16 berbeda sangat nyata dengan perlakuan P3 dengan nilai 5,09 P2 dengan nilai 5,07 dan P1 dengan nilai 4,98 tetapi tidak berbeda sangat nyata dengan perlakuan P0 dengan nilai 5,86 dan P5 dengan nilai 5,80. Hal yang sama pula pada perlakuan P3 dengan nilai 5,09 berbeda sangat nyata dengan perlakuan P4 dengan nilai 6,16 P0 dengan nilai 5,86 dan P5 dengan nilai 5,80 tetapi tidak berbeda sangat nyata dengan perlakuan P2 dengan nilai 5,07 dan P1 4,98. Hal ini menunjukkan bahwa panelis lebih menyukai tekstur yoghurt sinbiotik dengan perlakuan pada penambahan pati termodifikasi dari umbi uwi ungu ( Dioscorea alata) di P4 0,04 dengan nilai 6,16 yang termasuk dalam kategori lembut.

Penambahan pati termodifikasi dari umbi uwi ungu (Dioscorea alata) dalam yoghurt akan mempengaruhi tekstur, penampakan produk serta karakteristik lain dari yoghurt sinbiotik yang dihasilkan. Bila dibandingkan dengan jenis hikdrokoloid 
yang lain, pati lebih sering digunakan sebagai pengental karena prosesnya lebih mudah dan harganya juga lebih terjangkau. Menurut Jenie (2003), penggunaan kultur starter campuran dapat mereduksi lama fermentasi, sehingga menghasilkan sifat sensoris dan tekstur yang lebih baik. Kultur starter yang diberikan disetiap perlakuan semua sama yaitu $3 \%$.

Yoghurt sinbiotik yang diberi penambahan pati termodifikasi dari umbi uwi ungu (Dioscorea alata) teksturnya lembut dikarena pada umbi uwi ungu

\section{Kekentalan Yoghurt Sinbiotik Umbi Uwi Ungu (Dioscorea alata)}

Rataan nilai kekentalan pada yoghurt sinbiotik terhadap sifat sensoris yoghurt sinbiotik menggunakan pati termodifikasi dari umbi uwi ungu (Dioscorea alata) berkisar antara 4,32 6,07 dari perlakuan $\mathrm{P} 0$ - perlakuan.

Hasil analisis sidik ragam menunjukkan bahwa perlakuan penambahan pati termodifikasi dari umbi uwi ungu (Dioscorea alata) P0 0\%, P1 $0,1 \%, \mathrm{P} 2$ 0,2\%, P3 0,3\%, P4 0,4\% dan P5 $0,5 \%$ memberikan pengaruh yang berbeda sangat nyata $(\mathrm{P}<0.01)$ terhadap kekentalan yoghurt sinbiotik yang dihasilkan. Berdasarkan hasil uji lanjut BNJ menunjukkan bahwa kekentalan pada yoghurt sinbiotik dengan penambahan pati termodifikasi dari umbi uwi ungu
(Discorea alata) pada perlakuan P2 dengan nilai 6,07 tidak berbeda sangat nyata dibandingkan dengan perlakuan P1 dengan nilai 5,91 dan P4 dengan nilai 5,45 tetapi berbeda sangat nyata dengan perlakuan P0 dengan nilai 4,66 perlakuan P3 dengan nilai 4,59 dan perlakuan P5 dengan nilai 4,32. Hal ini menunjukkan bahwa panelis lebih menyukai kekentalan yoghurt sinbiotik dengan perlakuan pada penambahan pati termodifikasi dari umbi uwi ungu (Dioscorea alata) di P2 dengan nilai 6,07 yang termasuk dalam kategori kental.

Menurut Goncalves et al. (2005) yang menyatakan bahwa semakin banyaknya konsentrasi pengental kapasitas pengikatan air juga akan semakin meningkat. Kekentalan pada yoghurt dipengaruhi oleh penggumpalan yang terjadi. Fermentasi oleh bakteri Streptococcus thermophilus dan Lactobacillus bulgaricus yang menghasilkan konsistensi yoghurt yang menyerupai puding. Tingkat kekentalan yoghurt dapat dipengaruhi oleh beberapa faktor, seperti bahan utama penyusun yoghurt (jenis susu) dan lama penyimpanan. Disamping itu penambahan serat juga dapat mempengaruhi nilai kekentalan dan konsistensi produk yang dihasilkan. 


\section{Cita Rasa Yoghurt Sinbiotik Umbi Umbi Uwi Ungu (Dioscorea alata)}

Rataan nilai cita rasa pada yoghurt sinbiotik terhadap sifat sensoris yoghurt sinbiotik menggunakan pati termodifikasi dari umbi uwi ungu (Dioscorea alata) berkisar antara 4,77 - 6,02 dari perlakuan P0 - perlakuan P5.

Hasil analisis sidik ragam menunjukkan bahwa perlakuan penambahan pati termodifikasi dari umbi uwi ungu (Dioscorea alata) 0\%, 0,1\%, $0,2 \%, 0,3 \%, 0,4 \%, 0,5 \%$ memberikan pengaruh yang berbeda sangat nyata $(\mathrm{P}<0.01)$ terhadap cita rasa pada yoghurt sinbiotik yang dihasilkan. Berdasarkan hasil uji lanjut BNJ menunjukkan bahwa cita rasa pada yoghurt sinbiotik dengan penambahan pati termodifikasi dari umbi uwi ungu (Discorea alata) pada perlakuan P4 dengan nilai 6,02 berbeda sangat nyata dibandingkan dengan perlakuan P0 dengan nilai 5,00 P1 dengan nilai 4,77 P2 dengan nilai 4,93 dan P3 dengan nilai 5,14 tetapi tidak berbeda sangat nyata dengan perlakuan P5 dengan nilai 5,89. Hal yang sama juga terjadi pada perlakuan P3 dengan nilai 5,14 berbeda sangat nyata dengan perlakuan P0 dengan nilai 5,00 P1 dengan niali 4,77 dan $\mathrm{P} 2$ dengan nilai 4,93 tetapi tidak berbeda sangat nyata dengan perlakuan P4 dengan nilai 6,02 dan P5 dengan nilai 5,89. Hal ini menunjukkan bahwa panelis lebih menyukai cita rasa yoghurt sinbiotik dengan perlakuan pada penambahan pati termodifikasi dari umbi uwi ungu ( Dioscorea alata) di P4 dengan nilai 6,02 yang termasuk dalam kategori suka.

Menurut Abraham et al. (1993) menyatakan bahwa selama proses fermentasi yoghurt terjadi perombakan senyawa nutrisi terutama protein dan lemak oleh adanya aktivitas Lactobacillus Bulgaricus dan Strepthococcus Thermophillus dalam starter yoghurt. Hal ini akan berpengaruh terhadap sifat fisik, kimiawi dan organoleptik yoghurt sinbiotik. Menurut Chandan \& Shahani (1993 dalam Yusmarini \& Efendi, 2004), hasil metabolisme karbohidrat (gula) berupa asam - asam organik seperti asam laktat akan mempengaruhi cita rasa dan ikut menentukan kualitas yoghurt.

\section{KESIMPULAN}

Perlakuan dengan pemberian pati termodifikasi dari umbi uwi ungu (Dioscorea alata) sebanyak $0,4 \%$ memberikan nilai yang baik terhadap kualitas sensoris kususnya pada cita rasa 
dan tekstur rasa dan tekstur yoghurt sinbiotik.

\section{DAFTAR PUSTAKA}

Abraham, A.G., G.L. De Antoni and M.C. ANON.1993. Proteolitic activity of Lactobacillus bulgaricus grown in milk. Journal. Dairy Sci.76:14981505.

Abubakar, Budi. A dan A. Harsono. 1998. Pengaruh Suhu dan Macam Suhu Terhadap Mutu Yoghurt Selama Penyimpanan. Prosiding. Seminar Nasional Peternakan dan Veteriner. Bogor. Hal: 755-760.

Anindita. 2002. Pembuatan yakult kacang hijau. kajian tingkat pengenceran dan konsentrasi sukrosa. Skripsi. FTP. Universitas Brawijaya. Malang.

Chandan., R. C. dan K. M.Shahani. 1993. Yoghurt. In: Dairy Science and Technology Handbook. 2. Product Manufacturing. Y. H. Hui, Ed. VCH, Pub. Inc. USA.

Goncalves, D., C. Perez, G. Reolon, N. Segura, P. Lema, A. Gambaro, P. Varela dan G. Ares, 2005. Effect of thickemer on the texture of stirred yoghurt. Alim, Nutr. Araraquara. 16 (3) : 207-211.

Jenie, B. S. L. 2003. Pangan Fungsional Penyusun Flora Usus yang Menguntungkan. Makalah. Seminar Sehari Mikroflora Usus Bagi Kesehatan dan Kebugaran, Bogor.

Martin, F. dan R. Rubeste. 1976. The polyphenols of dioscorea alatayam tubers associated with oxidative browning. Journal agricultural Food Chemistry 14: 67-70.
Onimawo, I. dan P. Akubor. 2012. Food Chemistry (Integrated Approach with Biochemical Background) 2nd. Nigeria: Joytal Printing Press.

Salijata, M. G., R. S. Singhal, dan P. R. Kulkarni. 2006. Resistant starch-a review. Comprehensive Reviews in Food Science and Food Safety 5: $1-17$.

Steel, R. G. D. Dan J. H. Torrie. 1991. Prinsip dan Prosedur Statistik Suatu Pendekatan Biometrik. Edisi kedua. PT. Gramedia Pustaka Utama, Jakarta. (Diterjemahkan oleh B. Sumantri).

Suryono, M., Harijono, Yunianta. 2013. Pemanfatan Ikan Tuna (Yellowfin tuna), UBI JALAR (Ipomoea batatas) dan Sagu (Metroxylon sago sp) dalam Pembuatan Kamaboko. Journal Teknologi Pertanian 14 (1): 9-20.

Winarti, S., Harmayani, E. dan Nurismanto, R. (2011). "Karakteristik dan profil inulin beberapa jenis uwi (Dioscorea app.)". Journal AGRITECH 31:4,378-383

Yelnetty, A., M. Tamasoleng. 2019. The addition of Yam Tuber (Dioscorea alata) flour as a source of prebiotic on biomilk synbiotic characteristics. Prosiding. International Conference of Animal Science dan Teknologi (ICAST) IOP ConfI 247:012-052.

Yusmarini dan R. Efendi. 2004. Evaluasi mutu soyghurt yang dibuat dengan penambahan beberapa jenis gula. Jurnal Natur Indonesia 6(2): 104110. 